\title{
Underrepresentation of Women at Academic Excellence and Position of Power: Role of Harassment and Glass Ceiling
}

\author{
Rizwana Yousaf ${ }^{*}$, Rudi Schmiede ${ }^{2}$ \\ ${ }^{1}$ Sociology, Technische Universitaet, Darmstadt, Germany \\ ${ }^{2}$ Sociology (Work, Technology and Society), Technische Universitaet, Darmstadt, Germany \\ Email: *rizwana.yousaf@stud.tu-darmstadt.de,schmiede@ifs.tu-darmstadt.de
}

Received 20 January 2016; accepted 26 February 2016; published 29 February 2016

Copyright (C) 2016 by authors and Scientific Research Publishing Inc.

This work is licensed under the Creative Commons Attribution International License (CC BY). http://creativecommons.org/licenses/by/4.0/

(c) (i) Open Access

\begin{abstract}
The study intends to comprehend the underrepresentation of women on positions of power and academic excellence in academia. The study explained the role of exploitation and harassment, which might hinder, when women were trying to climb to top hierarchical position. The majority of women supervised by male heads, sexual harassment could be used as a glass ceiling to hamper women to reach top hierarchal level. The majority participants were working on lower academic and administrative hierarchy; they were experiencing harassment throughout the hierarchical level. Similarly, they considered that harassment could contribute to the underrepresentation of women at academic excellence and a position of power.
\end{abstract}

\section{Keywords}

Underrepresentation, Academia, Sexual Harassment, Glass Ceiling, Women

\section{Introduction}

Generations of women may have faced discrimination, harassment, male-dominating networks and intimidation globally [1]-[4]. Universities are facing increasingly complex challenges in attracting and retaining human capital [5], women are under-represented in academic excellence positions-positions of power, decision-making, and influence and if they try to move up of hierarchical scale, there will be a hype of exploitation and discrimination [6]-[14].

The women of Pakistan may be disadvantaged relative to men of the same class. Social and cultural factors ${ }^{*}$ Corresponding author.

How to cite this paper: Yousaf, R. and Schmiede, R. (2016) Underrepresentation of Women at Academic Excellence and Position of Power: Role of Harassment and Glass Ceiling. Open Journal of Social Sciences, 4, 173-185. 
can have historically hindered most of women from entering the job market [10]. But with the recent changes in society caused by expansion of educational facilities and increased access to learning encourage more and more women to enter the job market in almost all spheres especially in the education sector and in higher education institutes in Pakistan. According to Pakistan employment trends report (2013), women have particularly benefited nationally from the overall labour market, and women's participation has increased from $16.2 \%$ in 2001-2002 to $24.3 \%$ in 2012-2013. In spite of this trend, however, men benefit more from improvements in the labour market than women. In 2012-2013, 43.8\% of the adult male population had wage or salaried job as compared to $24.9 \%$ of females [15]. However, the majority of women are working on low echelons of hierarchical ladders. One of the biggest and oldest universities in Pakistan has a massive difference of number between male and female working on various hierarchical levels. The majority of women are working on low academic hierarchy, i.e. Lecturers [16]. As the majority of Pakistani women are poor and work very hard and long hours in very low productivity jobs, their social protection and safety networks are typically inadequate or totally missing. Therefore, the majority of female population cannot afford to be unemployed; they may face inequality, discrimination and sexual harassment as a part of the job [15].

Sexual harassment at workplace is leading form of gender based inequality which working women are facing today in Pakistan. Human Rights watchdog reports that in Pakistan, 68\% women are sexually harassed [17]. Still, many of them remain silent and reluctant to lodge formal or informal complaints of sexual harassment experiences in the workplace because of the fear of losing job, shame, stigmatization on women's repute and not wanting their families to know about their issues [18].

Some women may advance to the top of middle management and academic grades, but are unable to pass through this barrier [19]-[28] and reach top of management, along with many other suppressing factors, sexual harassment is one of the major factors which are hindering women to move the top of hierarchical position. According to some researchers, a contributing factor to women's low success in the labour market is sexual harassment at the workplace [29]-[43].

What is, perhaps, unexpected is that sexual harassment is found throughout the employment hierarchy and not simply among those working on low hierarchy. Although, a study by McLaughlin, Uggen and Blackstone (2009) find that "the strongest and most consistent finding concerns the greater risk of harassment of women in authoritative positions" [44]. According to surveys, 93\% of the women in Pakistan have reported one or other form of sexual harassment in their workplace [42] [44]. Other studies suggest that probably every Pakistani woman has been harassed at least once in public and workplace [33] [45] [46].

As the majority of women supervised by male bosses or heads so they might use, sexual harassment as a tool to prevent women to move up the hierarchy. Other studies suggested that in various complaints of sexual harassment at workplaces, in almost a quarter of cases, the alleged harasser was identified as the head of the institute or the person in a superior position [35] [47]. However, women trying to climb to top hierarchical position, they might face various discriminations including harassment. These positions have often come at a cost to women who are able to achieve them. These women might carry burdens of stereotyping, prejudice, sexual harassment, tokenism, and isolation [47].

In the last thirty years, acknowledgement of sexual harassment of women at the work place has reached a global scale [31] [48] [49]. Although, sexual harassment is an everyday crisis that hypothetically affects every woman [50]. Like Pakistan, discrimination against women is a continuing problem around the world [51]. These prohibitions provide criminal and/or individual penalties for such behaviour. Nonetheless, despite bans against sex discrimination, in most countries, women's lower earnings, status, sufferings and occupation of managerial positions when compared with men's provide evidence of gender inequality and discrimination continued its existence [14] [52].

In the United States, Europe and many other parts of the world, women who are low in hierarchical status, have low organizational power, earn significantly less than men, and are more frequent targets of sexual harassment [32] [53] in addition, women in lower status positions are more likely to be supervised or managed by men instead by women [32], which increases the risk of sexual harassment by their male superiors, bosses, colleagues and clients.

The action and behaviours of sexual harassment cannot be generalized globally due to the cultural differences of behaviour, perception, and normative values that vary throughout the world [36] [54], these variations are obvious in difference of organizational cultures, socialization and individual characteristics [38] [55]. It is a widespread observation that social-sexual normative behaviours may vary culture by culture. One act or gesture like 
putting a person as a sign of approval might be quite normal in one society, but could be highly offensive in other [56]-[58] especially in Pakistani cultural perspective [59].

Sexual harassment is difficult to define because it involves identifying the act and understanding the way it is perceived and experienced by women. Much of the touching, flirting and joking that goes on between the sexes is not sexual harassment because it is mutual. Sexual behaviour becomes harassment when it is unwanted and intrusive. In such cases, advancements are not welcomed, it offends and threatens the recipient [60] [61]. Recently, consensus has been made overwhelmingly that "sexual harassment is less about sexual desire than about control and domination" [44].

Various studies have established the link of glass ceiling and harassment with the underrepresentation of women at academic excellence and a position of power. Mostly we have western views in this regard, whereas perspectives on Asian and especially Pakistani society are missing or inadequate. This study would highlight the reasons and experiences of women in Pakistan.

\section{Literature Review}

The glass ceiling is a form of discrimination that is affecting women's lack of access to power and status in organizations. The term "the glass ceiling" refers to the invisible barrier stated that "the higher the post, the fewer the women". As an "invisible" barrier, the glass ceiling is difficult to eradicate through legislation. According to Cornell University, the "glass ceiling" is a metaphor first used by Nora Frenkiel in Adweek in March 1984 to explain the subtle, invisible obstacles women face after they attain mid-management positions. Despite professional eligibilities and ample opportunities, female employees are not aptly represented in the highest corridors of organizational power [62]-[64]. Informal networking and mentoring are frequently suggested as means of increasing the numbers of executive women [65], Further, networking with and mentoring offered by executive men can be less fruitful and more problematic for junior women, who may be assumed to be sexually involved with their mentors. In sum, the relative lack of women managers and executives, the support roles many women workers provide to men workers, and occupational sex-segregation all facilitate sexual harassment. Women who work for male supervisors or managers' report greater harassment and perceive their organizations as being more tolerant of harassment; women rarely perpetrate harassment; women view harassing behaviours differently from men [38].

The glass ceiling has remained a modern-day issue, with many surveys and reports being undertaken internationally [62] [66]-[71]. Although prejudices and discrimination towards women in the workforce have diminished, they still exist strongly for women in senior positions [71].

In the US, United Kingdom, Europe, Canada, Australia, New Zealand, Africa and Asia have found that women are less likely than men to be promoted to higher organizational levels, less likely to have tenure and more likely to hold part-time and limited-term appointments and to experience a pay gap [54] [72]-[74].

\section{Glass Ceiling Practices}

The glass ceiling is manifested in multiple ways: such as different pay for comparable work [65], sexual, ethnic, racial, religious discrimination or harassment in the workplace, the prevailing culture of many businesses, lack of family-friendly workplace policies [75]. Several other factors that impede the advancement of women in senior positions has been human capital barriers (lack of education, finances, resources, and experience); gender based stereotypes; discrimination and sexual harassment differences in communication styles; exclusion from informal networks; limited management support for work/life programs; lack of mentors and role-models; occupational sex segregation; and attitudinal and organizational biases [70] [76] [77]. Informal recruitment practices that fail to recruit women, lack of opportunities for training and mentorship, exclusion from informal networks, menial assignments rather than challenging assignments that would progress their careers, wage gaps between men and women despite comparable work, and placement in jobs that have very little advancement opportunities. Not only that there is strong evidence of the under-representation of women in leadership positions in many countries all over the world such as Sri Lanka [70], Japan [21], India [78] [79], Iran [80], Pakistan [8] [9], Malaysia [81], Australia [82] [83], New Zealand [25], China [84], France [85], Sweden [86], South Africa [87], United Kingdom [82] [88], Canada [89] and United States [90]-[92]. This literature has pointed that there are innumerable barriers, women are facing when they trying to climb the hierarchical ladder. Evidences suggest that they face an invisible barrier preventing their rise in leadership positions [86] [93]. 


\subsection{Glass Ceiling and Harassment in the World}

It is important to find the link of glass ceiling with harassment of women at work place. As far as, the harassment of women at work place in the developed world is concerned, two third of the complainants alleged that their harasser was in a superior position to them, reflecting a traditional sexual harassment profile of a superior/subordinate relationship [94]. In the United States and Europe women who are low in hierarchical status, have low organizational power, earn significantly less than men, and are more frequent targets of sexual harassment [32] [53]. In addition, women in lower status positions are more likely to be supervised or managed by men than by women [32] who increase the risk of sexual harassment by their male superiors, bosses, colleagues and clients.

In Bangladesh, large scale of women's entry into paid labour force has increased incidences of sexual harassment. Sexual harassment, work and mobility appear to be closely intertwined in Bangladesh. Women are forced to face double jeopardy when it comes to sexual harassment [95].

In Nepal, a research on sexual harassment in the workplace revealed that the problem of sexual harassment is highly prevalent in workplaces, as 53.84 per cent of women employee/workers reported that they have faced the problem of sexual harassment in their workplaces [96]. In Japan, a study conducted by the Ministry of Labour found that out of 2254 women respondent, two third were subject to sexually harass. Caran et al. (2010) has conducted a research to find out the existence of sexual harassment (SA) among professors in a public university in Brazil. The study found out that $40.7 \%$ of the study participants admitted being victims of SA at work, 59.3\% knew the fellow who had suffered SA and 70.4\% stated that it is a common problem in the Institution [97].

\subsection{Sexual Harassment and Glass Ceiling in Pakistan}

In Pakistan, women who hold low organizational influence, are allegedly more frequent targets of discrimination [98] [99] and harassment at work places [79] [97] [100].

Researchers have found that in Pakistan the incidents of sexual harassment occur widely, sexual experience happens in every possible place that two genders meet like co-education institutes, workplace, public places, etc. reported accounts includes staring, sexual comments, molestation and forms of unwanted physical contact, [33] [36] [42] [101]. It is also observed that (87\%) Pakistani female university students are reported to be harassed frequently at the cafeterias, classrooms and even in Professor's offices [98] [102], it is also reported female teachers are also frequently harassed in academic institutes [8] [103].

However, women in Pakistan may face many difficulties [104] [105] in accessing decision-making positions at the local, provincial and national levels, and are excluded from crucial political, social and economic processes [106]. The researcher made hypotheses on the basis of cited literature [22] [53] [73] [77] [91] [92] [107]-[112] that women may facing diverse discrimination and exploitations and harassment, which might be prohibiting the women to climb the hierarchical ladder or underrepresenting them at academic excellence and the position of power in Pakistan, [8] [9] [13] [104].

\section{Material and Methods}

The jurisdiction of the study was the province of Punjab, keeping in view of its socioeconomic developmental distinction (HDI) from other provinces [113]. The research employed maximum variation sampling to capture variation amongst women serving in various hierarchical positions $(16-21)$ in universities. At the same time it was also made sure to capture the variations in terms of institutional structure public, private and public-private sector universities were included to capture the variety of all types of institutions. Faculties were selected randomly in each university and in selected faculties all the departments were included in the sample. In the selected departments all the women working from scale 16 - 21 were the part of the sample. Specifically, all of the Universities in the sample were categorized general Universities. On the first stage, a list of employees was taken from the respective university's website (many universities do not update their websites regularly) so during the data collection phase already developed list was matched with existing faculty and amended if some of the employees had left the institute or were on leave. Those who were working at the time of data collection were included in the sample.

The choice of sample size is as important as is the choice of sampling scheme because it also determines the extent to which the researcher can make statistical and/or analytic generalizations. For correlational research de- 
signs, a minimum sample size of 30 represents a statistical power of only 0.51 for one-tailed tests for detecting a moderate relationship (i.e., $r=0.30$ ) between two variables at the $5 \%$ level of statistical significance, and a power of 0.38 for two-tailed tests of moderate relationships [114] is required. From the present research total 451 participants were selected and finally 411 questionnaires were collected, some of the respondents had lost the questionnaire and they were not intended to take a new one and some of them never found in their office despite repeated visits.

The data have been collected in a pen-paper survey, in most of the cases, questionnaires were handed over to the participants and later have been collected from them. Some of the participants asked the additional questions on collection date and after clarifications they handed over the survey. Some of the participants on second visit asked for further time to fill in the survey and took some more days to complete it.

Confidentiality and privacy were important concerns of this research; therefore the participant's identity and their institutes and department name were converted into pseudo name and identities. Participants were given inform consent forms and told that their participation in this study is voluntary. They are free to decide not to participate in this study or to withdraw at any time without consequence.

\section{Findings and Results}

There were $48.9 \%$ participants from large public, 7.8\% were from small public, $22.1 \%$ were from public-private and $22.2 \%$ participants were from a private university. The majority of the respondents, $91.1 \%$ were involved in research and academic activities, whereas only $8.9 \%$ were solely doing administrative work in academic departments.

As far as background variables of the participants were concerned, though the majority of the respondents, $73.2 \%$ were working on permanent tenure, whereas $22.9 \%$ were working on a contractual basis, contracts might last from six months to two years, usually the long term contracts (2 years) have equivalent provisions and benefits to regular employees but still their contract is subject to renewal based on performance which is often evaluated by the head of the departments after a year. There were only 3.9\% employees working as visiting faculty. Those who are working on contract or visiting basis were more vulnerable in terms of facing discriminations; they might be more non-reactive to such behaviours as their jobs are subject to renewals and approvals from the heads. They are less likely to complain the discrimination [4].

Substantial numbers of respondents (44.5\%) were having a Masters of Philosophy/Masters of Science (M. Phil/MS) degrees. Although 33.8\% of the participants had Masters degrees (equivalent to Bachelors). Only 14.8\% respondents have done Doctorates. Significant majority having varying work experience ranging from 1 - 10 years, and $61.1 \%$ respondents were married and $67.9 \%$ were living either in joint or extended families.

The findings of the present research showed that $52.3 \%$ of the participants have experienced harassment in universities, and $35.3 \%$ of participants said sometimes they experienced it (which also shows the occurrence at some or other point of their professional life) and $12.4 \%$ of the participants said, they have not experienced harassment at workplace. So in the present research, $87.6 \%$ of the participants have experienced sexual harassment in their respective university. Studies by Sandhu, Singh, \& Batra, (2015) and Caran et al. (2010) also showed that women working in universities have experienced harassment [29] [97]. Similarly, 79.3\% of the participants were of the view that sexual harassment could hamper to climb hierarchical ladder.

In response to the question, what causes the harassment $17.8 \%$ of the participants held women responsible for such behaviours. They were of the view that women's provocative dressing has a role with harassment, which actually invites such behaviour. At the same time, $14.8 \%$ of the participants were of the view that women's make up invites men to pass the comments or say something about their appearance, here participant has similar views as of those who think women's provocative dressing has a role with the sexual harassment at workplace. A study of Beiner (2007) found some contrary, but interesting facts about provocative dressing of women. She found those who dressed provocatively is not the ideal target for the would-be harasser, who appears motivated at least in part by his ability to dominate his victim. Provocative dress does not necessarily signify submissiveness, but instead may be an indication of confidence and assertiveness. Theses finding again endorse that the definition and perception of harassment vary from culture to culture. Although, comments about dress are used to undermine working women's authority [115].

On the other hand $17.5 \%$ of the participants were of the view that women's provocative dressing and patriarchal mindset simultaneously could be important for such experiences. One could assume that man wants to sup- 
press or dominates over the women, but on the other hand women provide such opportunities by dressing up in a way which might not be approved in society. Women should work to improve the qualities and mental capabilities instead of dressing provocatively. McCrady (2012) wrote in her research article that often she got the comment from parties and colleagues in the form of "What a pretty dress you have on" her clinical supervisor spent more time to seduce her. Apparently his behaviour was well known to our faculty, but they dealt with it by recommending the practicum only to men or to women they thought could handle it [116].

There were complaint of sexual harassment at workplaces in various parts of the world, in almost a quarter of cases; the alleged harasser was identified as the head of the organization or the person in a superior position [35], [47]. Women may face various discriminating attitudes, including harassment trying to climb the top hierarchical position. Women might have to pay the price of such positions in the form of prejudice, sexual harassment and tokenism [47]. So in order to find, who were the likely culprit, it asked the study participants if they have ever experienced sexual harassment from supervisor, boss or head of department? In responding to this question, $21.9 \%$ said never, $23.4 \%$ of the participants said rarely, $40.9 \%$ said, sometimes, $10.2 \%$ said often, $3.6 \%$ said very often. Similarly, it was asked for them if they have ever experienced sexual harassment from senior colleagues. Although $13.1 \%$ said never, $39.7 \%$ said rarely, $34.1 \%$ said, sometimes, $10.0 \%$ said often, $3.2 \%$ said very often. However, when it was asked for them if they have ever experienced harassment from co-worker? $25.1 \%$ said never, $32.6 \%$ said rarely, $26.8 \%$ said, sometimes, $13.4 \%$ said often, $2.2 \%$ said very often. Correspondingly, when it was asked if they have experienced harassment from junior colleagues? $36.7 \%$ of the participants said never, 31.6\% said rarely, 19.7\% said sometimes. 8.0\% said often, 3.9\% said often. Finally, it was also asked if they have experienced sexual harassment from students, $41.4 \%$ of the respondents said never, $26.8 \%$ said rarely, $15.6 \%$ said sometimes, $13.1 \%$ said often, $3.2 \%$ said very often.

The contradiction between perceived equality and on-going statistical inequality creates confusion; despite optimistic views that women have broken through barriers to senior positions, they are, in fact, still underrepresented in governance, directorship, and executive leadership [116]. In order to compare consistencies and contradictions in responses, it asked respondents, do they think that sexual harassment in universities could underrepresent women in academic excellence and a position of power and $15.1 \%$ strongly disagreed, $19.7 \%$ were disagreeing, $14.1 \%$ were neutral, $43.3 \%$ were agreed, $7.8 \%$ were strongly agreed. A study by Raburu (2015) has been conducted in Kenya and the findings of this research demonstrated that very few women have progressed into senior academic and professional ranks and their pace is slow. They continue to be hampered by the socio-cultural attitude towards women [117]. Despite professional eligibilities and ample opportunities, female employees are not aptly represented in the highest corridors of organizational power [62]-[64] [80].

In order to find out the relationship of harassment with the underrepresentation of women at academic excellence and a position of power it was asked do they think that those working on low organizational hierarchy are frequent targets of sexual harassment $9.2 \%$ were strongly disagreeing, $24.1 \%$ were disagreeing, $15.3 \%$ were neutral, $47.0 \%$ were agreed, $4.4 \%$ were strongly agreed. At the same time it was also asked if they think those who were working on high organizational hierarchy are frequent targets of sexual harassment $23.4 \%$ were strongly disagreeing, $28.5 \%$ were disagreeing, $29.2 \%$ were neutral, $14.4 \%$ were agreed, $4.6 \%$ were strongly agreed. As the majority of the participants were itself on low hierarchy, they might not be well aware of those who are on high organizational hierarchy.

Until recently it has been found that despite the pressures on universities to maximize their talent pool, women continue to be systemically underrepresented in senior academic and general staff positions in universities internationally [4] [66]. So finally it was asking the participants do they think that as the majority of the women in universities are working at low hierarchical positions, their underrepresentation at academic excellence and a position of power are the result of sexual harassment. On responding to this question, $16.3 \%$ strongly disagreed, $22.9 \%$ disagreed, $14.1 \%$ were neutral, $43.3 \%$ were agreed, and $3.4 \%$ were strongly agreed.

\section{Sexual Harassment Experience and Underrepresentation of Women}

According to McDonald, Charles worth, \& Graham (2015) sexual harassment at work remained a widespread phenomenon worldwide, despite laws and policies to control it. A study from India reveals that the majority of women managers (149) on the record, told they did not face sexual harassment at work place while working and climbing the corporate ladder, whereas the majority of them accepted in personal interactions and un-recorded verbal discussions that they did face sexual harassment at workplace [2]. However, they were not willing to put 
it on record [18]. So first of all, in order to find out the relationship between SH experience with various academic hierarchical levels following hypothesis has been developed.

Ha: Does a relationship exist between SH experience and hierarchical position of a woman in university?

As in the sample about $43.8 \%$ cells have expected count less than 5, so we have to look the Likelihood Ratio for the statistically significant results. Likelihood Ratio (Sig. 0.052) indicated that relationship does not exist between SH experience and hierarchical position of a woman in university (Table 1).

At the same time, another hypothesis developed to find if there was any relation between sexual harassment and underrepresentation of women in academic excellence and a position of power. The hypothesis is as follows: (Table 2).

Ha: Does a relationship exist between SH experience and underrepresentation of women on higher hierarchical position?

There are 37.5\% cells have expected count less than 5, so the Likelihood Ratio (Sig. 0.017) shows the statistically significant relationship exist between sexual harassment and underrepresentation of women at academic excellence and a position of power in university.

Phi value is more than 0.160 , which indicated the strength of the relationship is also strong.

Majority of Pakistan's female population may not afford to be unemployed as they came to employment after a long struggle. They may face inequality, discrimination and sexual harassment as a part of the job [15]. According to Fox and Xiao (2013) women who reach the top of hierarchical level, along with many other suppressing factors have experienced sexual harassment as one of the major factors which hindering women to move the top of hierarchical position. According to some researchers a contributing factor to women's low success in the labour market is sexual harassment at workplace [2] [27] [31]-[33] [35] [36] [105] [118]. What is, perhaps, unexpected is that sexual harassment is found throughout the employment hierarchy and not simply among those working on low hierarchy [44]. On the basis of above dissuasion following research question developed.

What are the percentage of women experiencing and considering SH underrepresenting them to academic excellence and a position of power as Lecturer, Assistant Professor, Associate Professor, Professors, Lab assistants and administrative officers?

\section{Hypothesis:}

Ha: Does difference exist in the percentage of sexual harassment experience and percentage of the consideration that SH underrepresenting women to academic excellence and a position of power between or among Lecturer, Assistant Professor, Associate Professor, Professors, Lab Assistants and Administration Offices?

Table 1. Chi-square sexual harassment experience and hierarchical position.

\begin{tabular}{cccc}
\hline & Chi-Square Tests & \\
\hline Pearson Chi-Square & Value & df & Asymp. Sig. (2-sided) \\
\hline Likelihood Ratio & $13.948^{\mathrm{a}}$ & 7 & 0.052 \\
Linear-by-Linear Association & 14.955 & 7 & 0.037 \\
N of Valid Cases & 1.250 & 1 & 0.264 \\
Total & 411 & & \\
\hline
\end{tabular}

Table 2. Chi-square for sh experience and underrepresentation at ae and pp.

\begin{tabular}{cccc}
\hline & & Chi-Square Tests & \\
\hline & Value & df & Asymp. Sig. (2-Sided) \\
\hline Pearson Chi-Square & $14.212^{\mathrm{a}}$ & 7 & 0.048 \\
Likelihood Ratio & 16.998 & 7 & 0.017 \\
Linear-by-Linear Association & 8.223 & 1 & 0.004 \\
N of Valid Cases & 411 & & \\
\hline
\end{tabular}

a. 6 cells $(37.5 \%)$ have expected count less than 5 . The minimum expected count is 0.41 . 
Table 3. Multivariate tests.

\begin{tabular}{|c|c|c|c|c|c|c|c|c|c|}
\hline & Effect & Value & $\mathrm{F}$ & Hypothesis df & Error df & Sig. & $\begin{array}{l}\text { Partial Eta } \\
\text { Squared }\end{array}$ & $\begin{array}{l}\text { Noncent. } \\
\text { Parameter }\end{array}$ & $\begin{array}{l}\text { Observed } \\
\text { Power }^{\mathrm{b}}\end{array}$ \\
\hline \multirow{4}{*}{ Intercept } & Pillai's Trace & 0.857 & $1.208 \mathrm{E} 3^{\mathrm{a}}$ & 2.000 & 404.000 & 0.000 & 0.857 & 2416.966 & 1.000 \\
\hline & Wilks’ Lambda & 0.143 & $1.208 \mathrm{E}^{\mathrm{a}}$ & 2.000 & 404.000 & 0.000 & 0.857 & 2416.966 & 1.000 \\
\hline & Hotelling's Trace & 5.983 & $1.208 \mathrm{E} 3^{\mathrm{a}}$ & 2.000 & 404.000 & 0.000 & 0.857 & 2416.966 & 1.000 \\
\hline & Roy’s Largest Root & 5.983 & $1.208 \mathrm{E}^{\mathrm{a}}$ & 2.000 & 404.000 & 0.000 & 0.857 & 2416.966 & 1.000 \\
\hline \multirow{4}{*}{$\begin{array}{l}\text { Under. } \\
\text { EE \& PP }\end{array}$} & Pillai's Trace & 0.035 & 1.435 & 10.000 & 810.000 & 0.160 & 0.017 & 14.348 & 0.731 \\
\hline & Wilks' Lambda & 0.965 & $1.437^{\mathrm{a}}$ & 10.000 & 808.000 & 0.159 & 0.017 & 14.375 & 0.732 \\
\hline & Hotelling's Trace & 0.036 & 1.440 & 10.000 & 806.000 & 0.158 & 0.018 & 14.401 & 0.732 \\
\hline & Roy’s Largest Root & 0.030 & $2.458^{\mathrm{c}}$ & 5.000 & 405.000 & 0.033 & 0.029 & 12.290 & 0.773 \\
\hline
\end{tabular}

a. Exact statistic; b. Computed using alpha = 0.05; c. The statistic is an upper bound on F that yields a lower bound on the significance level.

H0: No difference exists in the percentage of sexual harassment experience and percentage of the consideration that SH underrepresenting women to academic excellence and a position of power between or among Lecturer, Assistant Professor, Associate Professor, Professors, Lab Assistants and Administration Offices.

There were 211 Lecturers, 92 Assistant Professors, 24 Associate Professors, 19 Professors, 28 Lab in charge and 37 Administration Office employees. Box's Test for equality of covariance matrices shows that we do not have the co-variance of the dependent variables.

Researchers looking to see, do difference exist in the percentage of sexual harassment experience and consideration that SH underrepresenting women at academic excellence and a position of power between or among Lecturer, Assistant Professor, Associate Professor, Professors, Lab in charge and Administration Office employees.

Wilk's Lambda sig value is 0.732 which is quite larger than the significance level $(0.05)$ and at the same time all other multivariate results also show the results are statistically not significant. It shows no difference exist in the percentage of sexual harassment experience and consideration that SH underrepresenting women to academic excellence and a position of power between or among Lecturer, Assistant Professor, Associate Professor, Professors, Lab Assistants and Administration Offices. This indicates all the women working on various hierarchical levels who have experienced harassment at their workplace and they all endorse that SH might contribute towards the underrepresentation of women at academic excellence and a position of power. At the same time Partial Eta Squared value also shows the very weak relationship between or among the groups (Table 3).

\section{Discussion}

It is established that women in universities have experienced harassment throughout the hierarchal level, whereas they believe harassment could also hinder them to climb the hierarchical scale. Universities are facing increasingly complex challenges in attracting and retaining women [5] and are under-represented in managerial and academic excellence positions-positions of power, decision-making, and lack of influential positions could affect the women and social capital in general and specifically developing world.

\section{Conclusion}

Women have a different voice and therefore a different mode of leadership, this difference can bring new and positive values and become incorporated and accepted in social and cultural systems. A struggling economy, Pakistan, unlikely to lose talented women from its leadership pool, because they tend to gravitate toward nonhierarchical, consultative, collaborative, and interpersonally sensitive approaches, women can be assets in many leadership settings, intimidation and harassment can hamper women to perform effectively, whereas secure and harassment free space will benefit women and academia specifically and societies in general. 


\section{References}

[1] Hejase, H.J. (2015) Sexual Harassment in the Workplace: An Exploratory Study from Lebanon. Journal of Management Research, 7, 107-121. http://dx.doi.org/10.5296/jmr.v7i1.6965

[2] McDonald, P., Charlesworth, S. and Graham, T. (2015) Developing a Framework of Effective Prevention and Response Strategies in Workplace Sexual Harassment. Asia Pacific Journal of Human Resources, 53, 41-58. http://dx.doi.org/10.1111/1744-7941.12046

[3] Thomas, A. (2015) Incidents of Sexual Harassment at Educational Institutions in India: Preventive Measures and Grievance Handling. International journal of Research and Review in Health Sciences Recent Advances in Multidisciplinary Research, 2, 0317-0322.

[4] Liza, H.-W. and Sarah, T. (2014) Barriers to Women Leaders in Academia: Tales from Science and Technology. Studies in Higher Education, 41, 415-428. http://dx.doi.org/10.1080/03075079.2014.929102 http://papers.ssrn.com/sol3/papers.cfm?abstract_id=1979806

[5] Uche, C.M. and Jack, I.F. (2014) Level of Female Academic Staff Development and Mobility in University Of Port Harcourt. Research Journal in Organizational Psychology \& Educational Studies, 3, 152-158.

[6] Gobillon, L., Meurs, D. and Roux, S. (2015) Estimating Gender Differences in Access to Jobs. Journal of Labor Economics, 33, 317-363. http://dx.doi.org/10.1086/678495

[7] Saher, N., Ali, S.S. and Matloob, T. (2014) Cross-Cultural Management and Workplace Challenges for Women Managers in Pakistan: Exploring the Realities from an Emic Perspective. Journal of Basic and Applied Scientific Research, 4, 133-137.

[8] Jabbar, A. and Imran, A. (2013) Perception of Glass Ceiling in the Educational Institution: An Evidence from Pakistan. World Applied Sciences Journal, 23, 628-634.

[9] Batool, S.Q., Sajid, M.A. and Shaheen, I. (2013) Gender and Higher Education in Pakistan. International Journal of Gender and Women's Studies, 1, 15-28.

[10] Khan, D.M.M., Rehman, Z.U. and Dost, M.K.B. (2012) Glass Ceiling vs Employee Performance Impact on Employees’ Satisfaction Level in the Organization. Singaporean Journal of Business Economics, and Management Studies, 1, 5975. http://dx.doi.org/10.12816/0003747

[11] Ismail, U. (2012) Concept of "Glass Ceiling” in the Print Media of Pakistan. The Journal of the South East Asia Research Centre, 2, 69-77.

[12] Ahmed, M.A. and Hyder, A. (2009) Sticky Floors and Occupational Segregation: Evidence from Pakistan. Paper presented at 24th AGM of Pakistan Society of Development Economists.

[13] Ahmed, M.A. and Hyder, A. (2008) Sticky Floors and Occupational Segregation: Evidence from Pakistan. The Pakistan Development Review, 47, 837-849.

[14] Tomei, M. (2006) Gender Discrimination and Inequalities at Work: Some Policy Issues and Challenge. InFocus Programme on Promoting the Declaration on Fundamental Principles and Rights at Work, International Labour Office.

[15] Pakistan Employment Trends (2013) Government of Pakistan Statistics Division Pakistan Bureau of Statistics. http://www.pbs.gov.pk/sites/default/files/Labour\%20Force/publications/Pakistan_Employment_2013.pdf

[16] Fact Book (2012) University of the Punjab. http://pu.edu.pk/document/factbook-latest.pdf

[17] Naz, A.M.H., Daraz, U., Khan, W., Khan, T., Salman, M. and Muhamma, D. (2013) A Paradigm Shift in Women’s Movement and Gender Reforms in Pakistan (a Historical Overview). Global Journal of Human-Social Science Research, 13.

[18] D’Cruz, P. and Rayner, C., (2013) Bullying in the Indian Workplace: A Study of the ITES-BPO Sector. Economic and Industrial Democracy, 34, 597-619. http://dx.doi.org/10.1177/0143831X12452672

[19] Kakker, D.J. and Bhandhari, A. (2015) Perception of Women on Higher Education: A Study of Glass Ceiling in Delhi. Pezzottaite Journal, 4, 1430-1434.

[20] Helen, H.Y. (2014) An Examination of Women in Federal Law Enforcement. An Exploratory Analysis of the Challenges They Face in the Work Environment. Feminist Criminology, 10, 259-278.

[21] Nemoto, K. (2013) When Culture Resists Progress: Masculine Organizational Culture and Its Impacts on the Vertical Segregation of Women in Japanese Companies. Work, Employment \& Society, 27, 153-169. http://dx.doi.org/10.1177/0950017012460324

[22] Cochran, A., Hauschild, T., Elder, W.B., Neumayer, L.A., Brasel, K.J. and Crandall, M.L. (2013) Perceived Gender-Based Barriers to Careers in Academic Surgery. The American Journal of Surgery, 206, 263-268. http://dx.doi.org/10.1016/j.amjsurg.2012.07.044

[23] Gardner, S.K. and Blackstone, A. (2013) Putting in Your Time: Faculty Experiences in the Process of Promotion to 
Professor. Innovative Higher Education, 38, 411-425. http://dx.doi.org/10.1007/s10755-012-9252-x

[24] Machado-Taylor, M. and Özkanli, Ö (2013) Gender and Academic Careers in Portuguese and Turkish Higher Education Institutions. Ë̌itim ve Bilim-Education and Science, 38, 346-356.

[25] Harris, C.A. and Leberman, S.I. (2011) Leadership Development for Women in New Zealand Universities: Learning from the New Zealand Women in Leadership Program. Advances in Developing Human Resources, 14, 28-44.

[26] Amondi, O.B (2011) Representation of Women in Top Educational Management and Leadership Positions in Kenya. Advancing Women in Leadership, 31, 57-68.

[27] Fox, M.F., Xiao, W. (2013) Perceived Chances for Promotion among Women Associate Professors in Computing: Individual, Departmental, and Entrepreneurial Factors, The Journal of Technology Transfer, 38, 135-152. http://dx.doi.org/10.1007/s10961-012-9250-2

[28] Hult, C., Callister, R. and Sullivan, K. (2005) Is There a Global Warming Toward Women in Academia? Liberal Education, 91, 50-57.

[29] Sandhu, D.N., Singh, D. and Batra, S. (2015) Corporate Gender Discrimination: Analysis and Evaluation. International Journal of Organizational Behaviour \& Management Perspectives, 3, 1250-1257.

[30] Neall, A.M. and Tuckey, M.R. (2014) A Methodological Review of Research on the Antecedents and Consequences of Workplace Harassment. Journal of Occupational and Organizational Psychology, 87, 225-257. http://dx.doi.org/10.1111/joop.12059

[31] Okechukwu, C.A., Souza, K., Davis, K.D. and de Castro, A.B. (2014) Discrimination, Harassment, Abuse, and Bullying in the Workplace: Contribution of Workplace Injustice to Occupational Health Disparities. American Journal of Industrial Medicine, 57, 573-586. http://dx.doi.org/10.1002/ajim.22221

[32] Haarr, R.N. and Morash, M. (2013) The Effect of Rank on Police Women Coping with Discrimination and Harassment. Police Quarterly, 16, 395-419.

[33] Weiss, A.M. (2012) Moving Forward with the Legal Empowerment of Women in Pakistan. The United States Institute of Peace.

[34] Escartín, J., Salin, D. and Rodríguez-Carballeira, Á. (2011) Conceptualizations of Workplace Bullying: Gendered Rather than Gender Neutral? Journal of Personnel Psychology, 10, 157-165. http://dx.doi.org/10.1027/1866-5888/a000048

[35] Lockwood, N.R. (2007) Leveraging Employee Engagement for Competitive Advantage. Society for Human Resource Management Research Quarterly, 1, 1-12.

[36] Luthar, H.K. and Luthar, V.K. (2007) A Theoretical Framework Explaining Cross-Cultural Sexual Harassment: Integrating Hofstede and Schwartz. Journal of Labor Research, 28, 169-188.

[37] Barry, J., Berg, E. and Chandler, J. (2006) Academic Shape Shifting: Gender, Management and Identities in Sweden and England. Organization, 13, 275-298. http://dx.doi.org/10.1177/1350508406061673

[38] Scott, G. and Martin, B. (2006) Tactics against Sexual Harassment: The Role of Backfire. Journal of International Women's Studies, 7, 111-125.

[39] Guerrier, Y. and Adib, A. (2004) Gendered Identities in the Work of Overseas Tour Reps. Gender, Work \& Organization, 11, 334-350. http://dx.doi.org/10.1111/j.1468-0432.2004.00234.x

[40] International Labour Organization (2001) Action against Sexual Harassment at Work Place in Asia and the Pacific. Japan.

[41] Karega, R.G. (2002) Violence against Women in the Workplace in Kenya: Assessment of Workplace Sexual Harassment in the Commercial Agriculture and Textile Manufacturing Sectors in Kenya. International Labor Rights Fund Rights for Working Women Campaign, Washington DC.

[42] Anila (1998) Sexual Harassment at Workplace and Coping Strategies Employed by Women. PhD Thesis, National Institute of Psychology. Quaid-i-Azam University, Islamabad.

[43] Konrad, A.M. and Gutek, B.A. (1986) Impact of Work Experiences on Attitudes toward Sexual Harassment. Administrative Science Quarterly, 31, 422-438. http://dx.doi.org/10.2307/2392831

[44] Sarwar, F. and Nauman, B. (2011) Antecedents and Experience of Sexual Harassment at Individual and Group Level, 3rd SAICON International Conference on Management, Business, 29 Dec., Lahore.

[45] Yousaf, R. (2014) Perception of Professionals about Harassment of Women at Work Places and Women's Well Being. Journal of Research in Gender Studies, 1, 806-818.

[46] Yousaf, R. and Mahmood, N. (2012) Women's Professional Competence: An Effect of Harassment at Work Place. In: Khan, S., Saeed, Y. and Hafeez-ur-Rehman, Eds., Gender Main Streaming: An Analysis of Pakistani Society, Global Vision Publishing House, Delhi, 106-119. 
[47] Barreto, M.E., Ryan, M.K. and Schmitt, M.T. (2009) The Glass Ceiling in the 21st Century: Understanding Barriers to Gender Equality. In: Barreto, M., Ryan, M.K. and Schmitt, M.T., Eds., Psychology of Women Book Series, American Psychological Association, Washington DC, xvii 334 p. http://dx.doi.org/10.1037/11863-000

[48] Lim, S. and Lee, A. (2011) Work and Nonwork Outcomes of Workplace Incivility: Does Family Support Help? Journal of Occupational Health Psychology, 16, 95. http://dx.doi.org/10.1037/a0021726

[49] Popovich, P.M. and Warren, M.A. (2010) The Role of Power in Sexual Harassment as a Counterproductive Behavior in Organizations. Human Resource Management Review, 20, 45-53. http://dx.doi.org/10.1016/j.hrmr.2009.05.003

[50] Holmes, S. and Flood, M.G. (2013) Genders at Work: Exploring the Role of Workplace Equality in Preventing Men’s Violence against Women. White Ribbon Foundation, Sydney.

[51] Shaffer, M.A., Joplin, J.R.W., Bell, M.P., Lau, T. and Oguz, C. (2000) Gender Discrimination and Job-Related Outcomes: A Cross-Cultural Comparison of Working Women in the United States and China. Journal of Vocational Behavior, 57, 395-427. http://dx.doi.org/10.1006/jvbe.1999.1748

[52] Kahn, L.M. (2015) Wage Compression and the Gender Pay Gap. IZA (Institute for the Study of Labor) World of Labor, 1-10.

[53] Bell, M.P., McLaughlin, M.E. and Sequeira, J.M. (2002) Discrimination, Harassment, and the Glass Ceiling: Women Executives as Change Agents. Journal of Business Ethics, 37, 65-76. http://dx.doi.org/10.1023/A:1014730102063

[54] Equal Employment Opportunities Commission (2014) An Annual Report on EEOC Charges, Litigation, Regulatory Developments and Noteworthy Case Developments-FISCAL YEAR 2013. The Littler Report.

[55] Agocs, C., Attieh, R. and Cooke, M. (2004) Agents of Change? A Study of Equity Practitioners in Canadian Universities. In: Reimer, M., Ed., Inside Corporate U: Women in the Academy Speak out, Sumach Press, Toronto, 198-225.

[56] Gruber, J.E., Smith, M. and Kauppinen-Toropainen, K. (1996) Sexual Harassment Types and Severity: Linking Research and Policy. Sage Publications, Inc., Thousand Oaks.

[57] Cantisano, G.T., Domingez, J.F.M. and Depolo, M. (2008) Perceived Sexual Harassment at Capital. Federal Glass Ceiling Commission.

[58] Uggen, C. and Blackstone, A. (2004) Sexual Harassment as a Gendered Expression of Power. American Sociological Review, 69, 64-92. http://dx.doi.org/10.1177/000312240406900105

[59] Babar, Z.U. (2007) Violence against Women in Pakistan: Current Realities and Strategies for Change. European University Center for Peace Studies, Austria.

[60] Dey, D.P. (2013) Sexual Harassment at Workplace-An Empirical Study to Understand through the Lenses of Working Women of Guwahati, Assam, India. Journal Of Humanities And Social Science, 8, 77-82

[61] Gillani, Y.R. (2010) The Protection against Harassment of Women at the Workplace Act.

[62] Cook, A. and Glass, C. (2014) Women and Top Leadership Positions: Towards an Institutional Analysis. Gender, Work and Organization, 21, 91-103.

[63] Schwanke, D-A. (2013) Barriers for Women to Positions of Power: How Societal and Corporate Structures, Perceptions of Leadership and Discrimination Restrict Women's Advancement to Authority. Earth Common Journal Special Issue, 3, 15-28.

[64] Ghaus, B. (2013) Amidst the Barricades: Pakistani Women as Managers in Higher Education. The 3rd International Conference on Business and Management (ICOBM), Lahore, 27-28 February 2013, 2.

[65] Federal Glass Ceiling Commission (1997) The Glass Ceiling. In: Dunn, D., Ed., Workplace/Women's Place: An Anthology, Roxbury Publishing, Los Angeles, 226-233.

[66] Taylor-Abdulai, H.B., Sintim-Adasi, G. and Baafa, J. (2014) A Gendered Analysis of Promotional Issues in Higher Education: A Case Study of University of Ghana, Legon. Research on Humanities and Social Sciences, 4, 69-77.

[67] Bruckmüller, S., Ryan, M.K., Rink, F. and Haslam, A.S. (2014) Beyond the Glass Ceiling: The Glass Cliff and Its Lessons for Organizational Policy. Social Issues and Policy Review, 8, 202-232. http://dx.doi.org/10.1111/sipr.12006

[68] Catalyst (2013) Catalyst Research; Catalyst Historical List of Women CEO’s of the Fortune Lists: 1972-2013. http://www.catalyst.org/knowledge/fortune-500-ceopositions-held-women

[69] European Commission (2015) Employment and Social Developments in Europe 2014, Chapter 3, Section 3.3.2. The Gender Gap Varies Considerably from Country to Country. See the Education and Training Monitor 2014, 20.

[70] Bombuwela, P.M., and De Alwis, A.C. (2013) Effects of Glass Ceiling on Women Career Development in Private Sector Organizations-Case of Sri Lanka. Journal of Competitiveness, 5, 3-19.

[71] Kilgour, M.A. (2012) The Global Compact and Gender Inequality: A Work in Progress. Business \& Society, 52, 105-134. 
[72] Stanford Report (2014) Women Less Represented in Faculty, Staff Leadership Ranks. http://facultydevelopment.stanford.edu/sites/default/files/urm_report2_exe_sum.pdf

[73] Grund, C. (2014) Gender Pay Gaps among Highly Educated Professionals: Compensation Components Do Matter. http://hdl.handle.net/10419/96719

[74] Wilson, M., Gadbois, S. and Nichol, K. (2008) Is Gender Parity Imminent in the Professoriate? Lessons from One Canadian University. Canadian Journal of Education, 31, 211-228.

[75] Acker, J. (2006) Inequality Regimes Gender, Class, and Race in Organizations. Gender \& Society, 20, 441-464.

[76] Hannum, K.M., Muhly, S.M., Shockley-Zalabak, P.S. and White, J.S. (2015) Women Leaders within Higher Education in the United States: Supports, Barriers, and Experiences of Being a Senior Leader. Advancing Women in Leadership, 35, 67-77.

[77] Vinkenburg, C.J., van Engen, M.L., Eagly, A.H. and Johannesen-Schmidt, M.C. (2011) An Exploration of Stereotypical Beliefs about Leadership Styles: Is Transformational Leadership a Route to Women's Promotion? The Leadership Quarterly, 22, 10-21. http://dx.doi.org/10.1016/j.leaqua.2010.12.003

[78] Namita, D.R. and Neha, M.K. (2014) Sexual Harassment of Women at Work Place: Women Rights in India. Ademicia. An International Multidisciplinary Research Journal, 4, 1-13.

[79] Chaudhuri, P. (2010) Sexual Harassment of Women Health Workers. Health Providers in India: On the Frontlines of Change. 223.

[80] Dehaghani, M.V., Cholmaghani, G. and Goli, M. (2013) Factors Causing the Glass Ceiling in Public Organizations. International Journal of Scientific Research in Knowledge (IJSRK), 1, 106-115.

[81] Sharif, M.Y. (2015) Glass Ceiling, the Prime Driver of Women Entrepreneurship in Malaysia: A Phenomenological Study of Women Lawyers. Procedia-Social and Behavioral Sciences, 169, 329-336. http://dx.doi.org/10.1016/j.sbspro.2015.01.317

[82] Davidson, M.J. and Burke, R.J. (2012) Women in Management Worldwide: Progress and Prospects-An Overview. Women in Management Worldwide, No. 6.

[83] Maginn, P.J. (2010) Breaking through the Glass Ceiling of Local Government? The Gender Profile of Australian Mayors in Metropolitan Australia 1985-2010. FACTBase Paper No. 11.

[84] Tan, J. (2008) Breaking the "Bamboo Curtain” and the "Glass Ceiling”: The Experience of Women Entrepreneurs in High-Tech Industries in an Emerging market. Journal of Business Ethics, 80, 547-564. http://dx.doi.org/10.1007/s10551-007-9454-9

[85] Barnet-Verzat, C. and Wolff, F-C. (2008) Gender Wage Gap and the Glass Ceiling Effect: A Firm Level Investigation. International Journal of Manpower, 29, 486-502. http://dx.doi.org/10.1108/01437720810904185

[86] Peterson, H. (2015) Is Managing Academics “Women’s Work”? Exploring the Glass Cliff in Higher Education Management. Educational Management Administration \& Leadership.

[87] Booysen, L.A.E. and Nkomo, S.M. (2010) Gender Role Stereotypes and Requisite Management Characteristics: The case of South Africa. Gender in Management: An International Journal, 25, 285-300. http://dx.doi.org/10.1108/17542411011048164

[88] Thomson, P., Graham, J. and Lloyd, T. (2008) A Woman's Place Is in the Boardroom: The Roadmap. Palgrave Macmillan, Houndmills, Basingstoke, Hampshire.

[89] Cocchio, K.L. (2009) Executive Leadership for Women: Examining the Rhetoric and the Reality. Online Submission.

[90] Davis, D.R. and Maldonado, C. (2015) Shattering the Glass Ceiling: The Leadership Development of African American Women in Higher Education. Advancing Women in Leadership, 35, 50-66.

[91] Gago, S. and Macías, M. (2014) A Possible Explanation of the Gender Gap among Accounting Academics: Evidence from the Choice of Research Field. Accounting \& Finance, 54, 1183-1206. http://dx.doi.org/10.1111/acfi.12035

[92] Eagly, A.H. and Carli, L.L. (2007) Women and the Labyrinth of Leadership. Harvard Business Review, 85, 62-71.

[93] Ryan, M.K. and Haslam, S.A. (2005) The Glass Cliff: Evidence That Women Are Over-Represented in Precarious Leadership Positions. British Journal of Management, 16, 81-90. http://dx.doi.org/10.1111/j.1467-8551.2005.00433.x

[94] Australian Human Rights Commission (AHRC) (2012) Working without Fear: Results of the Sexual Harassment National Telephone Survey 2012. Australian Human Rights Commission, Sydney.

[95] Nari, U.K. (2003) Impact Assessment of Female Education Stipend Projects in Bangladesh. Role of NGO in Effective Implementation of PFA and CEDAW in Bangladesh, Dhaka: Social Development Services. Sponsored by Nari Uddug Kendra.

[96] International Labour Office (ILO) (2004) Global Employment Trends for Women 2004 (Geneva: International Labour Office). http://www.ilo.org/public/english/region/ampro/cinterfor/temas/informal/genero/doc.htm 
[97] Caran, V.C.S., Secco, I.A.D.O., Barbosa, D.A. and Robazzi, M.L.D.C.C. (2010) Moral Harassment among Professors in a Public University in Brazil. Acta Paulista de Enfermagem, 23, 737-744. http://dx.doi.org/10.1590/S0103-21002010000600004

[98] Ali, F. and Kramar, R. (2014) An Exploratory Study of Sexual Harassment in Pakistani Organizations. Asia Pacific Journal of Management, 229-249.

[99] Faiza, A. (2013) A Multi-Level Perspective on Equal Employment Opportunity for Women in Pakistan. Equality, Diversity and Inclusion. An International Journal, 32, 289-309

[100] Zakar, R., Zakar, M.Z. and Krämer, A. (2011) Spousal Violence against Women in the Context of Marital Inequality: Perspectives of Pakistani Religious Leaders. International Journal of Conflict and Violence, 5, 371-384.

[101] Punjab Development Statistic (2013) Bureau of Statistics Government of the Punjab Lahore. http://www.bos.gop.pk/system/files/Dev-2013.pdf

[102] Kashif, N.U., Ali, A. and Kelly, T.B. (2013) Perceptions and Practices of Social Behaviors among University Students in Pakistan. Far East Journal of Psychology and Business, 10, 35-45.

[103] Nasir, M. and Shaukat, A. (2013) A Study to Investigate the Physical and Psychological Effects of Sexual Harassment on Working Women in Kallaur Kot. International Journal of Educational Science and Research (IJESR), 3, 21-34.

[104] Sattar, T., Imtiaz, M. and Qasim, M. (2013) Gender Biased Discriminatory Factors Affecting the Carrier Progression of Female Employees in Private Organizations of Multan City (Pakistan). Journal of Economics and Sustainable Development, 4, 279-294.

[105] Nauman, B. and Abbasi, A.S. (2014) Sexual Harassment at Workplace... A Case of Banking Sector in Lahore. Middle-East Journal of Scientific Research, 20, 558-566.

[106] Rind, M.A. (2011) Women Empowerment in Pakistan. Participatory Youth Development Network.

[107] Grout, P.A., Park, I.U. and Sonderegger, S. (2009) An Economic Theory of Glass Ceiling: Women Executives as Change Agents. Journal of Business Ethics, 37, 65-75.

[108] Zeng, Z. (2011) The Myth of the Glass Ceiling: Evidence from a Stock-Flow Analysis of Authority Attainment. Social Science Research, 40, 312-325. http://dx.doi.org/10.1016/j.ssresearch.2010.06.012

[109] Anderson, L., Fryer, R. and Holt, C. (2006) Discrimination: Experimental Evidence from Psychology and Economics. In: Rogers, W., Ed., Handbook on the Economics of Discrimination, Edward Elgar Publishing, Cheltenham, 97-115.

[110] Reinhold, B. (2005) Smashing Glass Ceilings: Why Women Still Find It Tough to Advance to the Executive Suite. Journal of Organizational Excellence, 24, 43-55. http://dx.doi.org/10.1002/joe.20054

[111] Arfken, D.E., Bellar, S.L. and Helms, M.M. (2004) The Ultimate Glass Ceiling Revisited: The Presence of Women on Corporate Boards. Journal of Business Ethics, 50, 177-186. http://dx.doi.org/10.1023/B:BUSI.0000022125.95758.98

[112] Bose, C.E. and Whaley, R.B. (2001) Sex Segregation in the U.S. Labor Force. In: Vannoy, D., Ed., Gender Mosaics: Social Perspectives, Roxbury Publishing, Los Angeles, 228-248.

[113] Jamal, H. and Khan, A.J. (2007) Education Status of Districts: An Exploration of Inter-temporal Changes. Social Policy and Development Centre, Pakistan.

[114] Onwuegbuzie, A.J. and Collins, K.M.T. (2007) A Typology of Mixed Methods Sampling Designs in Social Science Research. The Qualitative Report, 12, 281-316. http://www.nova.edu/ssss/QR/QR12-2/onwuegbuzie2.pdf

[115] Beiner, T.M. (2007) Sexy Dressing Revisited: Does Target Dress Play in a Part in Sexual Harassment Cases. Duke Journal of Gender Law \& Policy, 14, 125-151.

[116] McCrady, B.S. (2012) Overcoming the Glass Ceiling: Views from the Cellar and the Roof'. Behavior Therapy, 43, 718-720.

[117] Raburu, P.A. (2015) Motivation of Women Academics and Balancing Family \& Career. Journal of Educational and Social Research, 5, 359-370. http://dx.doi.org/10.5901/jesr.2015.v5n1p359

[118] Yousaf, R. (2014) Professional Perception of the Harassment of Women in the Work Places and of Its Impact on Well-Being. Journal of Research in Gender Studies, 1, 806-818. 